МОНІТОРИНГ ПЕРЕДУМОВ ОСТРАКІЗМУ В НАВЧАЛЬНОМУ СЕРЕДОВИЩІ

\title{
MONITORING OF PREREQUISITES FOR OSTRACISM IN THE LEARNING ENVIRONMENT
}

Стаття присвячена визначенню складників моніторингу передумов соціальної ізоляції в соціальному середовищі. Особливу увагу приділено аналізу основних системних структур з указаної теми та систематизаціїї для створення схеми моніторингу передумов остракізму.

Здійснено спробу аналізу особливостей i закономірностей неприйняття індивідів у соціальному середовищі як передумов остракізації, які впливають на фрормування вказаного явища й можуть стати причинами соціального відторгнення. Зокрема, у цьому контексті розглянуто моделі поведінки особи; низький рівень регулювання мотиваціі та саморегулячії психоемоційних станів; особистісної невизначеності індивіда.

Висвітлені основні наукові погляди на зміст та фрункції спостереження за передумовами остракізації особистості, які є взаємозалежними та відповідають за забезпечення формування умов. Визначено, що основними завданнями психологічного моніторингу для просрілактики остракізму є моральне виховання, стимулювання учасників освітнього процесу до розвитку, гуманізація педагогічного процесу та продуктивна взаємодія учнівського, педагогічного і батьківського колективів.

Вказано на взаємозалежність між змістом та ффункціями моніторингу передумов остракізації, підтверджено важливість дотримання системного підходу до організації моніторингу та забезпечення психологічних аспектів соціально-екологічного середовища, яке характеризується: формуванням толерантного ставлення до всіх учасників навчального процесу; високим рівнем ефрективності психологічно-профрілактичної роботи; включеністю психологічної групи в діяльність освітнього процесу.

Розглянуто етапи моніторингу передумов остракізації в окремих освітніх закладах, професійні ффункції психолога й сочіального педагога, які відповідають за організацію контролю за передумовами остракізму для ефрективного супроводу освітянського процесу.

Зроблено висновки в системі моніторингу передумов остракізму в навчальному середовищі, що організація ефективного контролю за передумовами остракізму уможливлює попередження входження процесу остракізації в діяльність навчального закладу. Подальший розгляд проблеми вбачаємо в дослідженнях, присвячених основним проявам остракізованої особистості в середовищі освіти, що виникають у разі загрози приналежності, неоднозначності, невизначеності ситуацій і відмови у взаєминах.

Ключові слова: остракізм, соціальна ізоляція, моніторинг передумов, передумови остракізації, освітянський простір, контроль рівня остракізації.
The article is devoted to determining the features of monitoring the preconditions of social exclusion in the social environment. Particular attention is paid to the analysis of the main system structures on the specified topic and their systematization to create a scheme for monitoring the preconditions of ostracism.

An attempt is made to analyze the features and patterns of non-acceptance of individuals in the social environment as prerequisites for ostracization, which influence the formation of this phenomenon and can cause social rejection. In this context, these phenomena are also considered: models of personality behavior; low level of regulation of motivation and self-regulation of psycho-emotional states; personal uncertainty of the individual.

The main scientific views on the content and functions of observing the prerequisites of ostracization of personality are clarified. It is determined that the main tasks of psychological monitoring for the prevention of ostracism are moral education, stimulation of participants of the educational process to development, humanization of the pedagogical process and productive interaction of student, pedagogical and parental collectives.

The interdependence between the content and the functions of monitoring the preconditions of ostracization is pointed out, the importance of adhering to the systematic approach of the organization of monitoring and providing of social and ecological environment is confirmed. The latter is characterized by the formation of a tolerant attitude towards all participants of the educational process; a high level of efficiency of psychological and preventive work; the involvement of the psychological group in the activities of the educational process.

The stages of monitoring the preconditions of ostracization in separate educational institutions, the professional functions of a psychologist and social educator responsible for organizing the control of the preconditions of ostracism for effective support of the educational process are considered.

Conclusions have been made in the system of monitoring the prerequisites of ostracism in the educational environment that the organization of effective control over the prerequisites of ostracism makes it possible to prevent the ostracization process from appearing in the educational institution. Further consideration of the problem is seen in studies of the main manifestations of the ostracized personality in the educational environment, arising from the threat of belonging, ambiguity, uncertainty of situations and refusal of relations.

Key words: ostracism, social isolation, monitoring of preconditions, preconditions of ostracization, educational space, control of ostracization level.

Рівненський державний

гуманітарний університет

Постановка проблеми. Явище остракізації - описане та визнане в усьому світі як форма насильницької поведінки, яка виявля- ється серед молоді шкільного віку та призводить до безпрецедентної шкоди психічному та фізичному здоров'ю учасників освітнього 
процесу. Важливо розмежовувати негативні або тривожні ознаки в освітньому середовищі, що здатні призвести до більш деструктивних форм соціального неприйняття, таких як булінг, фізичні знущання, мобінг та пряма агресія. А моніторинг забезпечує суб'єктів освітнього простору необхідною інформацією про процес соціалізації в середовищі освіти.

Нині опосередковане неприйняття окремих учасників навчального процесу може спостерігатися серед студентів університету як результат конкурентоспроможної та індивідуалістичної культури, а також продовження підліткового віку, що, безумовно, впливає на динаміку міжособистісних взаємин студентів в умовах університету.

Міністерство охорони здоров'я США вказує на те, що підлітки та молодь (від десяти до двадцяти чотирьох років) становлять 29\% світового населення. Значна частина цієї групи вступає до вищих навчальних закладів, не виходячи з періоду пубертатного віку, що зумовлює потребу в розширенні спектра вивчення передумов утворення тенденцій остракізації, оскільки вплив жорстокого поводження може спричинити різни типи проблем для жертв, такі як стрес, зниження самооцінки, тривожність, депресія, низький рівень домагань, формування суїцидальних нахилів.

Розуміння механізмів остракізації, що стає можливим під час аналізу передумов, розкриває проблему остракізму в освітньому просторі - це тема, яка замовчується або позбавляється першочерговості в університетах, хоча вимагає більш глибокого усвідомлення на основі культурного різноманіття учасників процесу. Це форма насильства, яка може чинити шкідливий вплив на діяльність студентів та їхню професійну підготовку, формувати негативні світоглядні установки у майбутніх фахівців.

G. Sposito зазначає, що процес вивчення передумов остракізму в умовах освітнього простору сягає 1980 року. На початку досліджень науковцями використовувались для обговорення насильства в школі процеси руйнувань та пошкоджень шкільних будівель. Наприкінці 90-х та на початку 2000-х років дослідження почали детальніше вирішувати питання агресивних міжособистісних взаємин за участю учнів, викладачів та інших агентів шкільної громади в початкових та середніх школах; університети об'єктом аналізу не стали.

Щорічна звітність Міністерства освіти звертає увагу на індивідуалістичні, конкурентоспроможні та навіть агресивні дії, які дуже поширені в сучасному суспільному співіснуванні, вони зазвичай відтворюються в освітньому просторі й можуть виражати дискримінацію, нетерпимість і відсутність поваги до інших. Це поступово переходить у простір юридичного вирішення та організацію цього середовища через систему покарання об'єктів та суб'єктів освітнього простору.

Остракізація є одним з етапів створення групи та соціалізації особистості, тому моніторинг передумов остракізації, розробка спільних дій, розуміння явища та виявлення першоджерел його формування $€$ важливим завданням освітянського простору.

Отже, необхідним є психологічний аналіз зазначеної проблеми, метою якого стане вивчення особливостей моніторингу передумов формування остракізму i, як наслідок, створення схеми контролю рівня остракізації для вчасного попередження розвитку цього явища в середовищі освіти.

Аналіз останніх досліджень і публікацій. Остракізм зараховують до типу насильницької, агресивної, безперервної та навмисної поведінки (Olweus D., 2007; Smith A., 2004; Swearer G., 2010.). D. Silva (2010) вказує на страх як на стійкий чинник, який може слугувати першоджерелом остракізації індивіда в шкільному колективі. S. Lopes Neto (2005) підкреслює, що коли немає засобів для каталізації та мінімізації агресії, результатом буде погано скерований конфлікт. A Basil (1998) наголошує, що найбільшим завданням для освітнього простору $є$ визнання різноманітності як невіддільної частини національної ідентичності та оприлюднення багатства, представленого етнічною та культурною різноманітністю у складі соціокультурної спадщини, спрямовуючи на подолання будь-якої форми дискримінації. E. Debarbieux (2002) звертав увагу на аналіз діяльності остракізованих індивідів та проблеми їхніх сімей. А P. Freire (2011) зазначає, що демократична мотивація слухати та уважно дивитися на учасників навчального процесу може змінити дискурс педагогів до побудови свободи та творчості.

Постановка завдання. Мета статті - здійснити теоретичний аналіз системних структур моніторингу передумов соціальної ізоляції в соціальному середовищі; висвітлити основні положення наукових публікацій з указаної теми, систематизувати їх, створити схему моніторингу передумов остракізму.

Відповідно до зазначеної мети було висунуто такі завдання:

1) проаналізувати особливості й закономірності неприйняття індивідів у соціальному середовищі як передумови остракізації;

2) систематизувати зміст та функції спостереження за передумовами остракізації особистості;

3) висвітлити етапи моніторингу передумов остракізації в окремих освітніх закладах.

Виклад основного матеріалу. Освітній простір - це фізична та психологічна структура, яка забезпечує відображення всіх свідомих та несвідомих проєкцій через харак- 
тер взаємин з мініпроєкцією світу в умовах середовища. Це стає ключовим аспектом можливого вивчення остракізаторських тенденцій та розкриває структури його моніторингу. Вчені Пенсильванського університету виокремлюють такі передумови остракізації індивіда в освітянському просторі:

- модель поведінки особи - шаблони поведінкових сценаріїв індивіда, які характеризують його діяльність та соціальну взаємодію;

- низький рівень регулювання мотивації - схильність індивіда до апатичних настроїв, байдужості до участі в суспільній діяльності;

- низький рівень саморегуляції психоемоційних станів - невміння керувати власними асоціальними проявами, емоціями та імпульсами. Схильність до лабільності емоційних станів особистості, спалахів агресії, істерії [13, с. 19-34];

- особистісна невизначеність індивіда - відсутність в особи великої кількості точної інформації про власні поведінкові та когнітивні прояви. Вона включає неусвідомлення або фрустрацію щодо структурних компонентів існування особистості [8, с. 381-388].

Урахування цих передумов формування остракізаторських тенденцій у просторі освіти зумовлює потребу наведених нижче принципів організації контролю за передумовами остракізму, які, можливо, екстраполюють в умови українського освітнього простору, а саме:

1) принцип диференційованого підходу застосування індивідуального підходу під час роботи, диференціюючи осіб за особливостями поведінкових проявів, які їм притаманні. Цей принцип передбачає врахування психологічних індивідуальних відмінностей, відхід від вивчення характеристик групи або виявлення загальних психологічних процесів, які стосуються всіх учасників осередку [5, с. 6-15];
2) принцип першочерговості підкреслює співпереживання актуальних проблем учасників навчального процесу, концентрує увагу на позитивних поведінкових проявах особистості в колективі. Він вимагає дотримання принципів паритетності й рівності між колективами учнівського простору та педагогічного супроводу, дає змогу зосередитись на шляхах взаємодії, які допоможуть покращити самоактуалізацію кожного з учасників. Цей принцип спрямований на підкріплення цінності почуттєвого аспекту індивіда [6, с. 1726-1738];

3) принцип системності - вагомий відсоток уваги приділено практичному аспекту роботи з психологічними та організаційними проблемами колективу. Принцип вимагає безпосереднього включення психолога освітнього закладу в корекційний та профілактичний процеси, спрямовані на виявлення застійних моделей поведінки в групах остракізаторського типу та вирішення або зміну цих моделей безпосередньо незалежно від аналізу причини. Ключовим моментом цього принципу $є$ практична допомога системам змінити себе, запровадивши творчі «підштовхування» [9, с. 124-135];

4) принцип гласності-орієнтація на емоції учасників освітянського простору, запобігання утворенню остракізаторських проявів за допомогою максимальної відкритості в діяльності всіх осередків навчального процесу і свободи інформаційного простору в цьому навчальному закладі [14, с. 361-373];

5) принцип послідовності - застосування послідовного мотиваційного, профілактичного впливу на особу за допомогою вербальних та невербальних механізмів сприйняття для унеможливлення утворення тенденцій остракізму. Цей принцип передбачає використання послідовності включення інформації в свідоме

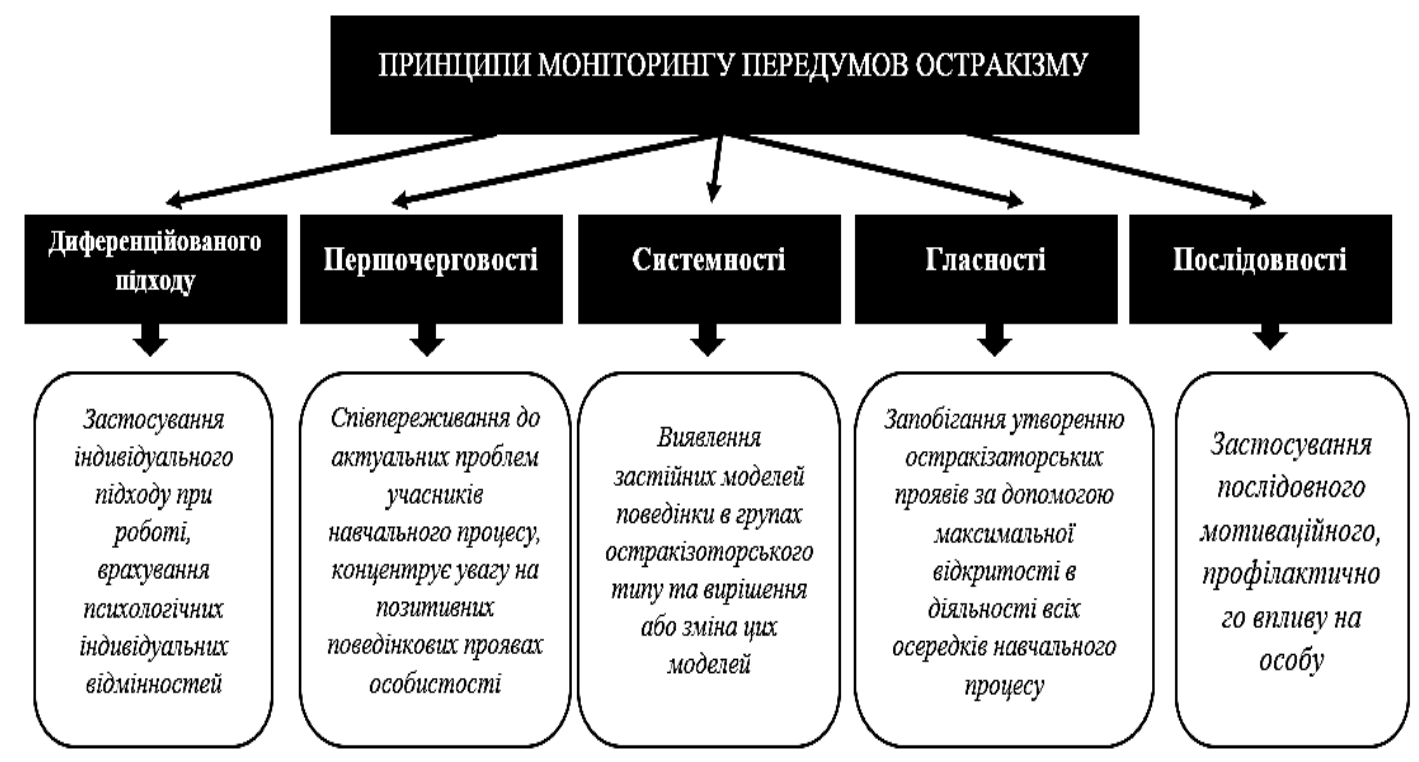

Рис. 1. Принципи моніторингу передумов остракізму в освітньому середовищі 
і несвідоме індивідуального навчання, групових процесів та міжгрупової діяльності [3] (див. рис. 1).

Цей аналіз дає змогу розкривати зміст моніторингу передумов остракізму в освітньому просторі в такий спосіб, як:

- виховання високої моралі та основ усвідомленої толерантності;

- створення комфортних умов для високого рівня духовно-морального виховання;

- гуманізація педагогічного процесу, демократизація взаємин у колективі;

- урахування інтересів і особливостей усіх учасників навчального процесу;

- створення умов для вільного вибору учнями світоглядних позицій;

- організація профілактичної роботи з батьками [4, с. 58-60].

Аналіз указаних змістових структур розкриває в освітньому просторі нові можливості для своєчасного контролю первинних деструктивних ознак остракізації в навчальному середовищі.

Отже, психолог і соціальний педагог, які відповідають за організацію контролю за передумовами остракізму, виконують такі професійні функції, зумовлені змістом моніторингу утворення остракізаторських нахилів і тенденцій у колективах навчального закладу (див. рис. 2):

1). Організаторські:

- планування і координація всієї виховної роботи з учасниками процесу;
- надання допомоги учнівській, педагогічній та батьківській організаціям навчального закладу;

- організація конструктивної взаємодії з учнівськими, педагогічними та батьківськими, громадськими колективами;

- забезпечення єдності загальноприйнятих нормативних вимог до всіх учасників освітнього процесу;

- ведення психологічної документації [2, с. 12-60].

2). Аналітико-узагальнюючі:

- сприяння всебічному розвитку учнів на основі вивчення і врахування їхніх індивідуально-психологічних характеристик;

- створення безпечного екологічного простору для вільного самовираження та комфортної взаємодії в освітньому середовищі [1].

3). Координаційно-інформаційні:

- забезпечення узгодженої роботи учнівського, педагогічного, батьківського колективів;

- повідомлення педагогічного складу про можливість виникнення ситуації остракізму в цьому навчальному закладі [2, с. 12-60].

4). Психологічні:

- встановлення довірливих взаємин з усіма учасниками освітянського процесу [12, с. 163-181].

5). Стимулюючо-гальмівні:

- активізація гуманістичних нахилів учасників освітнього процесу;

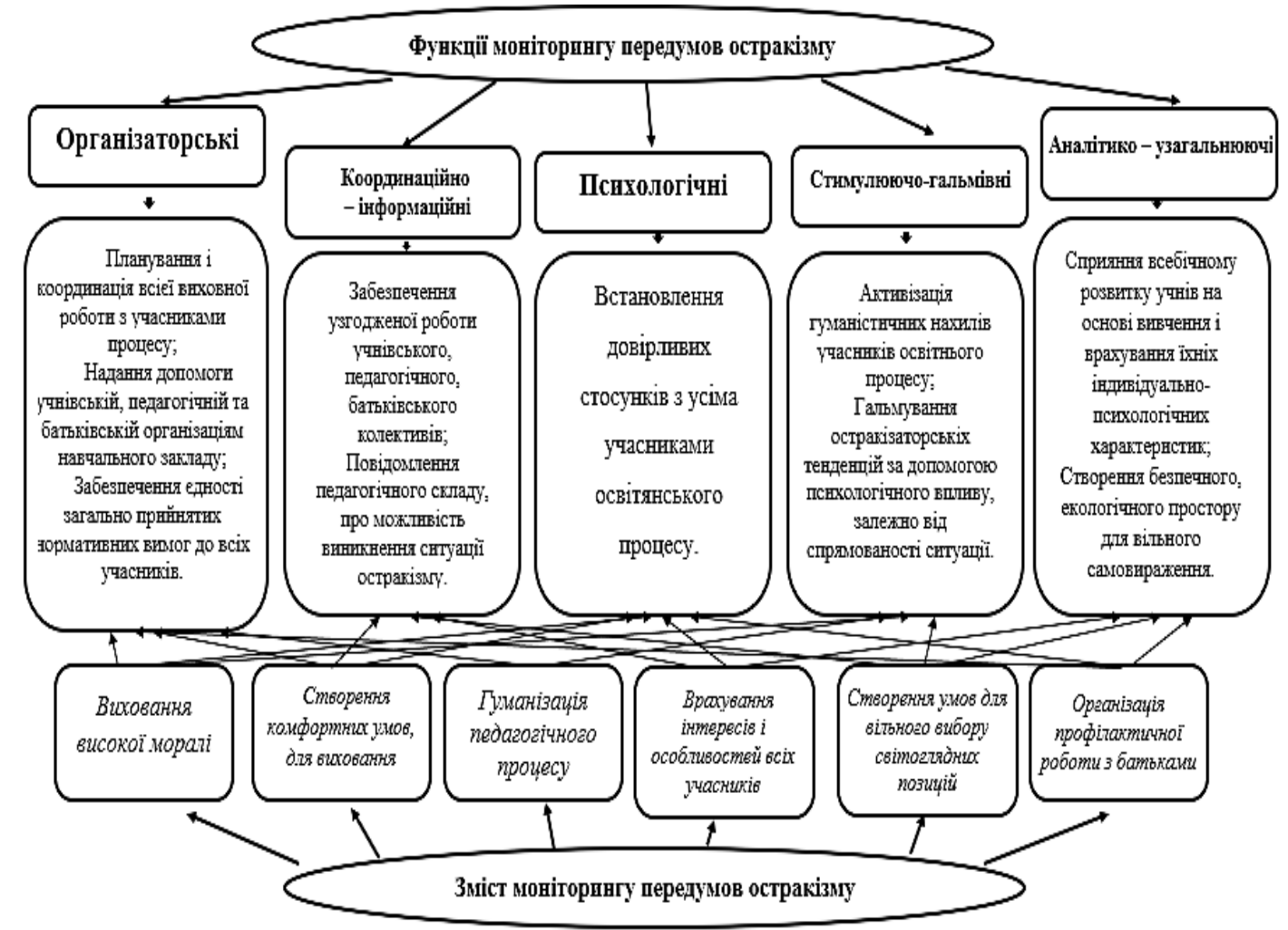

Рис. 2. Взаємозв'язок змісту та функцій роботи психолога під час моніторингу передумов остракізму 
- гальмування остракізаторськихтенденцій за допомогою психологічного впливу залежно від спрямованості ситуації [12, с. 163-181].

Систематизація особливостей та закономірностей неприйняття особистості, які максимально ефективно піддаються контролю у разі врахування функціонального навантаження роботи психолога в освітніх установах, забезпечує розкриття змісту та функцій спостереження за передумовами остракізації індивіда в освітньому просторі.

Виконання та дотримання системного підходу до змісту та функцій контролю моніторингу дає можливість забезпечення соціально-екологічного середовища, яке характеризується такими показниками, як:

- гуманне ставлення до особистості;

- повага прав і свобод учасників освітнього процесу;

- пред'явлення об'єкту освітнього процесу посильних і розумно сформульованих вимог;

- надання учасникам навчального простору права проявляти індивідуально-притаманні та бажані риси й особливості поведінки [11, с. 291-301];

- доведення до свідомості особистості конкретних цілей її виховання;

- ненасильницьке формування толерантного ставлення до всіх учасників навчального процесу;

- високий рівень ефективності психологічно-профілактичної роботи;

- включеність психологічної групи в діяльність освітнього процесу;

- активна співпраця і співтворчість між учнівським та педагогічним колективами [10].

На основі вказаних особливостей моніторингу передумов остракізму в навчальному середовищі було розроблено схему моніторингу передумов остракізму, яка містить такі структурні елементи, як:

1. Стисла характеристика колективу та окремих учнів:

- загальні відомості про учнів та їхні сім'ї;

- суспільна й пізнавальна активність;

- відповідальність за загальну справу;

- самодисципліна;

- уміння долати труднощі;

- культура поведінки в школі та поза нею;

- повага до особливих індивідуальних проявів членів колективу.

2. Вивчення морально-виховних завдань, які були поставлені минулого року (аналіз причин невиконання).

3. Аналіз змісту морального педагогічного виховання (перелік звичок, навичок, умінь, які формувались).

4. Аналіз використовуваних методів роботи (власного прикладу, переконання, стимулювання, доручення, бесіди, пояснення, гри, змагань).
5. Аналіз використовуваних форм психолого-профілактичної виховної роботи (класних годин, зборів, екскурсій, колективних творчих заходів).

6. Аналіз умов психологічного виховання:

- санітарно-побутових;

- екологічних;

- естетичних;

- фізіологічних;

- соціально-культурних [7, с. 54-59].

7. Аналіз засобів виховання:

- колективу (рівень згуртованості, наявність лідерів, остракізованих індивідів, неформальних груп спілкування);

- системи суспільних відносин;

- особистості вчителя, психолога, соціальних працівників;

- системи учнівського самоврядування (визначення його ефективності).

8. Аналіз результативності індивідуальної психологічної роботи:

- 3 учнями, схильними до остракізації інших;

- з обдарованими дітьми;

- з виключеними, неприйнятими в колективі.

9. Аналіз роботи з батьками:

- взаємодії;

- проведення батьківських зборів, їхня результативність.

10. Аналіз психологічної роботи:

- вивчення реального рівня морально-психологічного виховання учасників навчального процесу;

- вивчення ступеня відповідності реальних результатів і поставлених цілей;

- характеристика динаміки змін рівня остракізації за роками навчання.

11. Додатки: карта спостереження за остракізованою особистістю, рівень прояву остракізаторських тенденцій у колективі.

Застосування запропонованої схеми моніторингу передумов остракізму дає можливість системного вивчення факторів і передумов формування остракізаторських тенденцій у сфері освіти, підходить для діагностики та профілактики, коли йдеться про психічне здоров'я учнівського та педагогічного колективу. Схема допомагає виявити першоджерела формування явища остракізму в навчальному просторі, робить реальним попередження входження процесу остракізації в діяльність навчального закладу за допомогою методів навмисного та усвідомленого корегування деструктивних поведінкових проявів всіх учасників процесу.

Висновки. Теоретичний аналіз аспектів моніторингу передумов остракізму в навчальному середовищі дав змогу систематизувати першопричини остракізації індивідів, які провокуються: шаблонами поведінкових сцена- 
ріїв особи, схильністю індивіда до апатичних настроїв, невмінням керувати власними емоційними проявами та імпульсами, а також особистісною невизначеністю.

Аналізуючи теоретичні відомості, які висвітлюють проблему моніторингу остракізації в навчальних закладах, досліджено, що формування явища виключення окремих індивідів з колективу зумовлює потребу в таких принципах організації контролю за передумовами остракізму: диференційованого підходу, що застосовується для індивідуального підходу, здійснюваного завдяки диференціації осіб за особливостями поведінкових проявів, які їм притаманні; першочерговості, що підкреслює співпереживання до актуальних проблем учасників навчального процесу, концентрує увагу на позитивних поведінкових проявах особистості в колективі; системності, який переважно спрямований на виявлення застійних моделей поведінки в групах остракізаторського типу та вирішення або зміну цих моделей безпосередньо незалежно від аналізу причини; гласності - орієнтований на емоції учасників освітянського простору; послідовності - застосування послідовного мотиваційного, профілактичного впливу на особу за допомогою вербальних та невербальних механізмів сприйняття.

На основі узагальнення стану розробленої проблеми вказано на такі завдання психологічного моніторингу для профілактики остракізму, як: виховання високоморальних позицій в учасників учнівських колективів; гуманізація педагогічного процесу, демократизація взаємин у колективі; зважання на інтереси й особливості всіх учасників навчального процесу; організація профілактичних заходів.

Представлено та проаналізовано таку класифікацію професійних функцій, зумовлених змістом системи моніторингу остракізаторських нахилів і тенденцій у колективах навчального закладу:

- організаторські (планування і координація всієї виховної роботи з учасниками процесу);

- аналітико-узагальнюючі (сприяння всебічному розвитку учнів на основі вивчення і врахування їхніх індивідуально-психологічних характеристик);

- координаційно-інформаційні (забезпечення узгодженої роботи учнівського, педагогічного, батьківського колективів);

- стимулюючо-гальмівні (активізація гуманістичних нахилів учасників освітнього процесу).

Констатовано зв'язок між змістом та функціями моніторингу передумов остракізації, підтверджено важливість дотримання системного підходу для організації моніторингу та забезпечення соціально-екологічного середовища, яке може буде представлене: гуманним ставленням до особистості учня; доведенням до свідомості особистості конкретних цілей її виховання; високим рівнем ефективності психологічно-профілактичної роботи; активною співпрацею і співтворчістю між учнівським, педагогічним та батьківським колективами.

Здійснено спробу розробити схему контролю передумов остракізму, яка представлена такими складниками, як:

1. Стисла характеристика колективу та окремих учнів.

2. Вивчення морально-виховних завдань, які були поставлені минулого року (аналіз причин невиконання).

3. Аналіз змісту морального педагогічного виховання (перелік звичок, навичок, умінь, які формувались).

4. Аналіз використовуваних методів роботи (власного прикладу, переконання, стимулювання, доручення, бесіди, пояснення, гри, змагань).

5. Аналіз використовуваних форм психолого-профілактичної виховної роботи (класних годин, зборів, екскурсій, колективних творчих заходів).

6. Аналіз умов психологічного виховання.

7. Аналіз засобів виховання.

8. Аналіз результативності індивідуальної психологічної роботи.

9. Аналіз роботи з батьками.

10. Аналіз психологічної роботи.

11. Додатки: карта спостереження за остракізованою особистістю, рівень прояву остракізаторських тенденцій у колективі.

Виявлено, що організація ефективного контролю за передумовами остракізму робить реальним попередження входження процесу остракізації в діяльність навчального закладу за допомогою методів навмисного та усвідомленого корегування деструктивних поведінкових проявів усіх учасників процесу та своєчасного дослідження передумов остракізації.

Подальший розгляд цієї проблеми вбачаємо в більш розгорнутому вивченні основних проявів остракізованої особистості в середовищі освіти, що виникають у разі загрози приналежності, неоднозначності, невизначеності ситуацій і відмови у взаєминах; дослідженні взаємозалежності моніторингу та рівня остракізації в освітянському просторі.

\section{ЛITEPATУРA:}

1. Браун Р. Межгрупповые отношения. Перспективы социальной психологии. 2001. Москва: Эксмо.

2. Науменко Л.Ю. Виховна робота із запобігання ізоляціонізму та ксенофобії серед студентів Дніпропетровської державної медичної академії. Медичні перспективи, 2009. № 4, с. 12-16.

3. Ріттер Ф.Е. Для того, щоб дізнатися, як послідовність тем впливає на навчання. Окссрордська серія про когнітивні моделі та архітектури. 2007. Оксфорд; Нью-Йорк : Oxford University Press. 
4. Скулкина Е.Н. Индивидуально-психологические детерминанты формирования социальных установок ксенофробии у подростков. Психопедагогика в правоохранительных органах, 2015. № 60 , с. $58-60$.

5. Фішер А.Ф. Відсутність групи узагальнення до індивіда є загрозою для дослідження людських предметів. PNAS , 2018. № 27, с. 6106-6115.

6. Atkinson A. \& Adolphs R. The neuropsychology of face perception: beyond simple dissociations and functional selectivity. Philosophical Transactions of the Royal Society of London: Series B, Biological Sciences, 2011. No. 366, pp. 1726-1738.

7. Cunningham W. \& Brosch T. Motivational salience: amygdala tuning from traits, needs, values, and goals. Current Directions in Psychological Science, 2012. No. 21, pp. 54-59.

8. Masten, C.L. An fMRI investigation of empathy for 'social pain' and subsequent prosocial behavior. Neuroimage, 2011. No. 55, pp. 381-388.
9. Netzer L. \&Van KleefG.A. \& Tamir M. Interpersonal instrumental emotion regulation. Journal of Experimental Social Psychology, 2015. No. 58, pp. 124-135.

10. Olweus D., Limber S.P., Flerx V.C., Mullin N., Riese J. \& Snyder M. Olweus bullying prevention program. 2007. Center City, MN : Hazelden.

11. Smith A. \&Williams K.D. R U There? Effects of ostracism by cell phone messages. Group Dynamics: Theory, Research, and Practice, 2004. No. 8, pp. 291-301.

12. Sheppes, G. Emotion regulation choice: a conceptual framework and supporting evidence. Journal of Experimental Psychology. General, 2014. No. 143, pp. 163-181.

13. Williams K. \& Zadro L. Ostracism: the indiscriminate early detection system. New York: Psychology Press, 2005. No. 1, pp. 19-34.

14. Wolf W., Levordashka A., Ruff J., Kraaijeveld S., Lueckmann J. \& Williams K. Ostracism Online: Asocial media ostracism paradigm. Behavioral Research Methods, 2015. No. 47, pp. 361-373. 